\title{
EXPERIMENTAL INVESTIGATION ON SELF-HEALING BACTERIAL CONCRETE
}

\author{
Vidhya Lakshmi.A ${ }^{1}$, Arul Gideon.R ${ }^{2}$, Karthikeyan.K ${ }^{3}$, Uthayakumar.P ${ }^{4}$ \\ ${ }^{1,2,3,4}$ PG Student, Department of Civil Engineering, Sree Sastha Institute of Engineering and Technology, \\ Chembarambakkam, Chennai, TamilNadu-600123.
}

\begin{abstract}
The service life of the structure have reduced in today's construction field due to the low durability, strength factors and various other properties of concrete structures exposed to the environment. A novel strategy to restore or remediate cracks formed in the structures is bio-mineralization of Calcium Carbonate using microbes such as Bacillus. This research gives the information about increasing the durability of the concrete structure by introducing bacterial cell and other required nutrients for the process of biocalcification where the micro-organisms secrete Calcium Precipitate which in the presence of Carbonate ion forms Calcium Carbonate(Calcite) layer thus self-healing the cracks. Thus the durability of the concrete structure will increase and a study has to be carried out with concrete cubes subjected to bacterium.
\end{abstract}

Keywords: Bacteria, Bacillus Pasteurii, Calcium Carbonate, Compressive Strength, Water Absorption. $* * *$

\section{INTRODUCTION}

Concrete is the recurrently used building material. It has the advantage of being formed into any desired shape most conveniently. It is an artificial stone acquired by mixing aggregates, cement and water and allowing the product to cure for hardening. It's essential attributes are cement and water which react with each other chemically, to form another material having the serviceable strength. The strength of concrete depends upon the quality of its attributes, their relative quantities and the manner in which they are mixed, compacted and cured. It is possible to produce concrete of different specifications for various purposes by suitably adjusting the proportions of cement, aggregate and water.

It is essential for the structures that the serviceability should be above board. So as to attain this serviceability the minor cracks in the structure should be avoided which later may cause the structure to deteriorate. The cracks in the structure can be sealed or remediated without any repairing works. The process of self healing of cracks can be implemented to self heal the cracks and thus the repairing and rehabilitation can be avoided.

\section{MATERIALS AND METHODS}

\subsection{Materials}

The materials used in this research work are ordinary Portland cement of 53 grade, river sand, coarse aggregate of $20 \mathrm{~mm}$ nominal size, calcium lactate and bacteria Bacillus Pasteurii.

\subsection{Preparation of Specimens}

Concrete mix proportions of ratio $1: 1.5: 3$ is used for the preparation of specimens. Conventional specimens were casted. Bacterial specimens where the water is replaced by the bacterial solution of about $20 \%, 30 \%$ and $40 \%$ are also casted in parallel. The specimens were cured under tap water at room temperature and tested at the age of 7,14 and 28days.

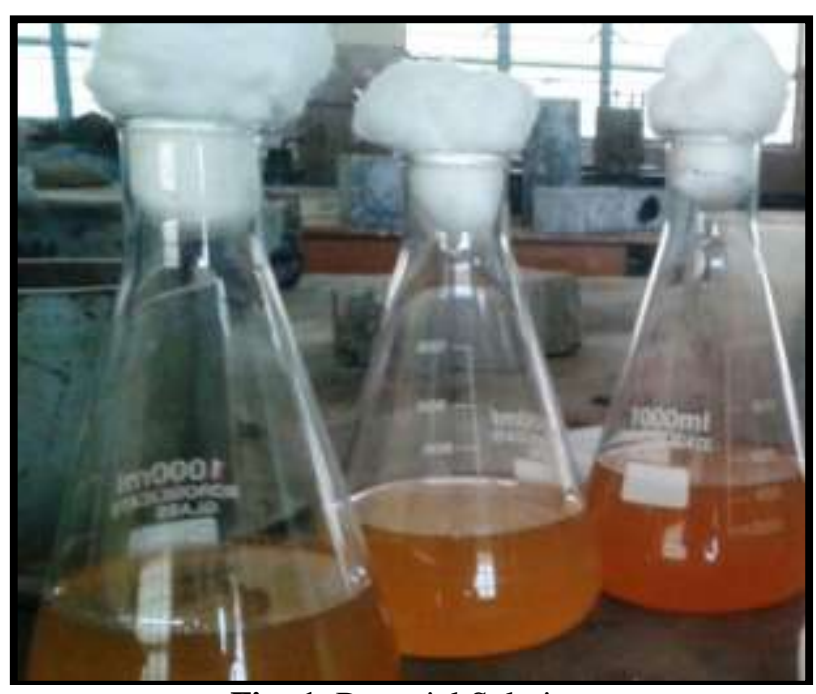

Fig -1: Bacterial Solution

\section{TESTS ON CONCRETE}

\subsection{Compressive Strength Test}

The casted specimens of size $150 \mathrm{~mm} * 150 \mathrm{~mm} * 150 \mathrm{~mm}$ cubes were tested to determine the compressive strength at the age of 7,14 and 28days.

\subsection{Water Absorption Test}

The sizes of $150 \mathrm{~mm} * 150 \mathrm{~mm} * 150 \mathrm{~mm}$ cubes were tested to determine the water absorption percentage at the age of 28days. 


\section{RESULTS AND DISCUSSION}

The various results obtained from the compressive strength test and water absorption tests were discussed and tabulated. The charts representing the test results were also provided. The table 1 indicates the results of the compressive strength of the conventional concrete cubes whereas the table 2, 3, 4 indicates the results of the compressive strength of the bacterial concrete cubes with 20\%, 30\% and $40 \%$ of bacterial solution respectively. The table 6 indicates the results of the water absorption of the conventional concrete and the bacterial concrete. The comparative results of compressive strength and water absorption of the conventional concrete cubes and bacterial concrete cubes were indicated in the table 5 and 7 respectively.

Table -1: Conventional Concrete Cubes

\begin{tabular}{|l|l|l|l|}
\hline \multirow{2}{*}{ Trial } & \multicolumn{3}{|l|}{ Compressive Strength N/mm } \\
\cline { 2 - 4 } & 7days & 14days & 28days \\
\hline 1 & 16.02 & 22.19 & 24.66 \\
\hline 2 & 14.30 & 19.81 & 22.01 \\
\hline 3 & 13.79 & 19.09 & 21.22 \\
\hline
\end{tabular}

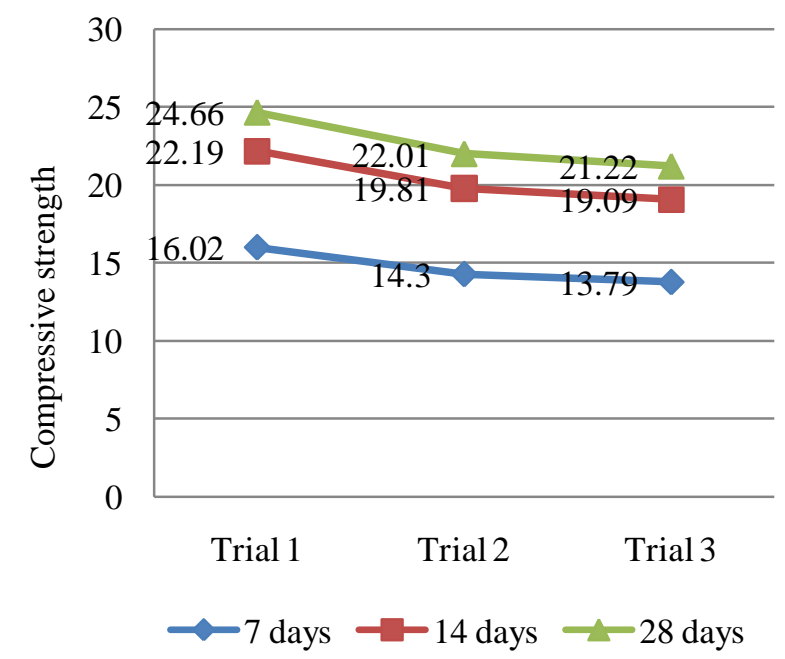

Chart -1: Compressive strength of Conventional Concrete Cubes

Table -2: Bacterial Concrete cubes with $20 \%$ of bacteria and $2 \%$ of calcium lactate

\begin{tabular}{|l|l|l|l|}
\hline \multirow{2}{*}{ Trial } & \multicolumn{3}{|l|}{ Compressive Strength N/mm } \\
\cline { 2 - 4 } & 7days & 14days & 28days \\
\hline 1 & 14.59 & 20.21 & 22.45 \\
\hline 2 & 15.08 & 20.88 & 23.21 \\
\hline 3 & 13.38 & 18.53 & 22.74 \\
\hline
\end{tabular}

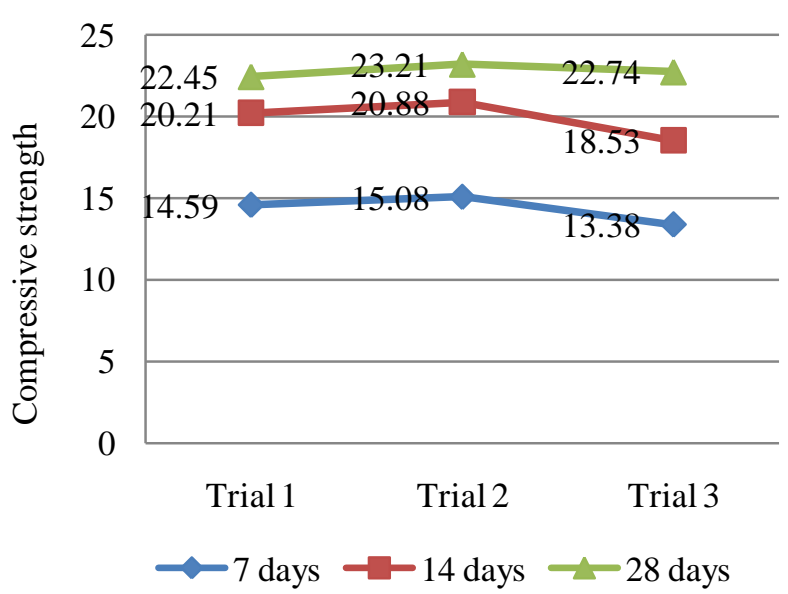

Chart -2: Compressive strength of Bacterial Concrete cubes with $20 \%$ of bacteria

Table -3: Bacterial Concrete cubes with $30 \%$ of bacteria and $2 \%$ of calcium lactate

\begin{tabular}{|l|l|l|l|}
\hline \multirow{2}{*}{ Trial } & \multicolumn{3}{|l|}{ Compressive Strength N/mm } \\
\cline { 2 - 4 } & 7days & 14days & 28days \\
\hline 1 & 14.28 & 19.78 & 21.98 \\
\hline 2 & 15.80 & 21.88 & 24.32 \\
\hline 3 & 14.32 & 19.83 & 22.03 \\
\hline
\end{tabular}

Table -4: Bacterial Concrete cubes with $40 \%$ of bacteria and $2 \%$ of calcium lactate

\begin{tabular}{|l|l|l|l|}
\hline \multirow{2}{*}{ Trial } & \multicolumn{3}{|l|}{ Compressive Strength N/mm } \\
\cline { 2 - 4 } & 7days & 14days & 28days \\
\hline 1 & 13.17 & 18.24 & 22.45 \\
\hline 2 & 14.38 & 19.92 & 22.13 \\
\hline 3 & 15.26 & 21.24 & 23.49 \\
\hline
\end{tabular}

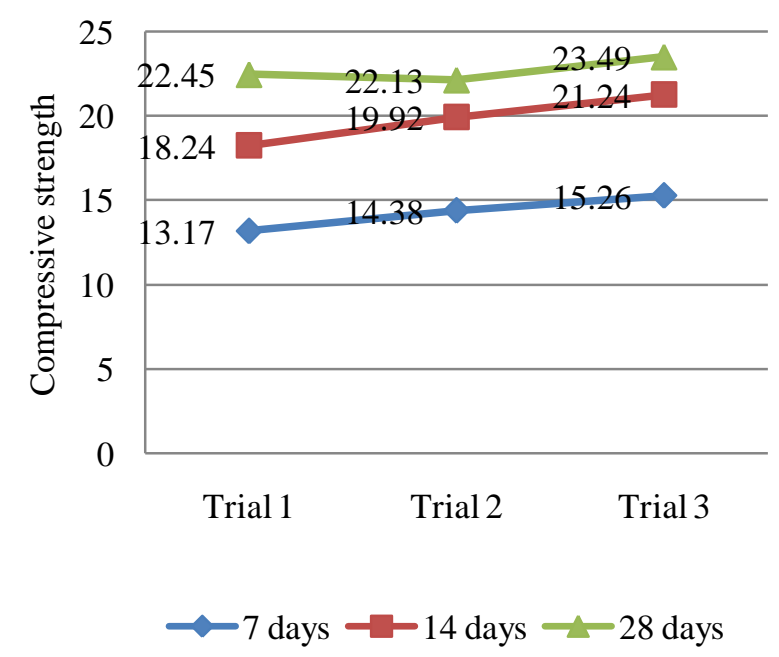

Chart -3: Compressive strength of Bacterial Concrete cubes with $30 \%$ of bacteria 
Table -5: Comparison of Compressive Strength results

\begin{tabular}{|l|l|l|l|l|}
\hline \multirow{2}{*}{ S.No. } & \multicolumn{4}{|l|}{$\begin{array}{l}\text { Average Compressive Strength } \\
\text { N/mm }\end{array}$} \\
\cline { 2 - 5 } & \multirow{2}{*}{$\begin{array}{l}\text { Conventional } \\
\text { concrete }\end{array}$} & \multicolumn{3}{|l|}{ Bacterial concrete } \\
\cline { 3 - 5 } & $\mathbf{2 0 \%}$ & $\mathbf{3 0 \%}$ & $\mathbf{4 0 \%}$ \\
\hline 1 & 22.63 & 22.80 & 22.77 & 22.69 \\
\hline
\end{tabular}

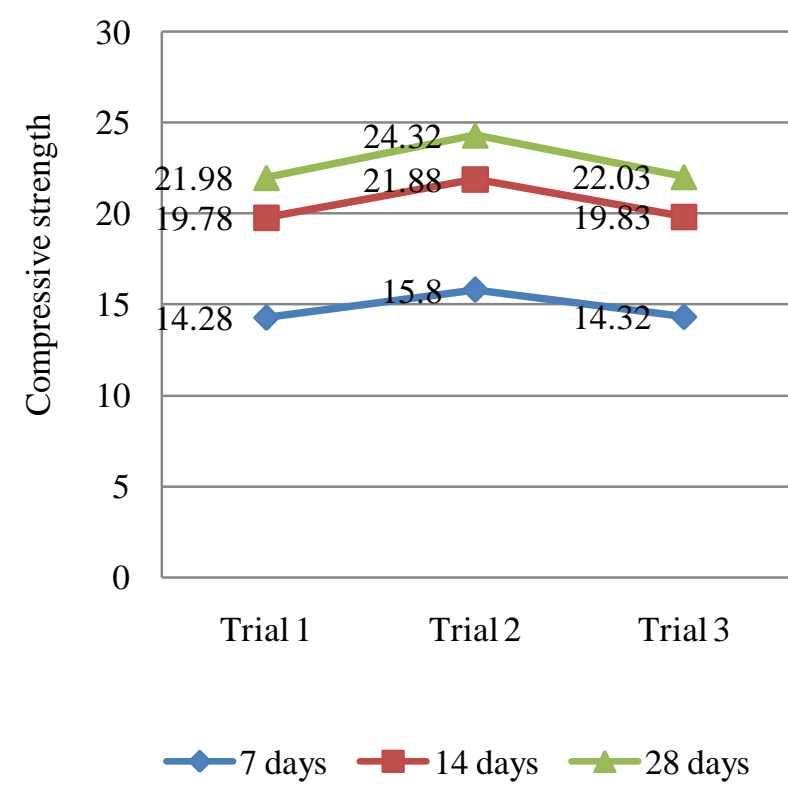

Chart -4: Compressive strength of Bacterial Concrete cubes with $40 \%$ of bacteria

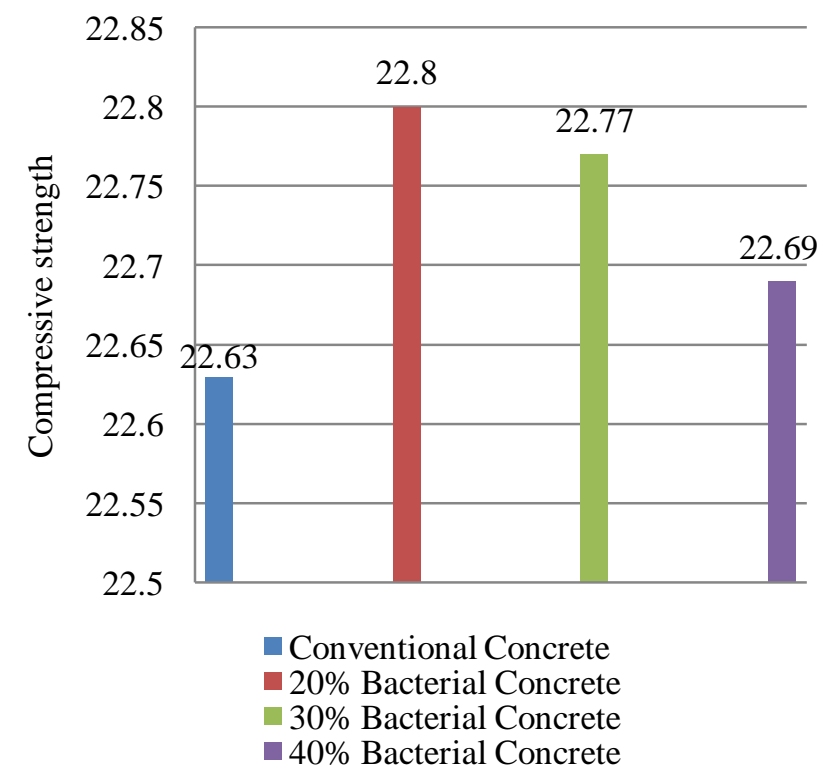

Chart -5: Comparison of Compressive strength of concrete cubes
Table -6: Water absorption of concrete cubes in percentage

\begin{tabular}{|c|c|c|c|c|}
\hline \multirow[t]{3}{*}{ S.No } & \multicolumn{4}{|c|}{ Water Absorption in \% } \\
\hline & \multirow{2}{*}{$\begin{array}{l}\text { Conventional } \\
\text { Concrete }\end{array}$} & \multicolumn{3}{|c|}{ Bacterial concrete } \\
\hline & & $20 \%$ & $30 \%$ & $40 \%$ \\
\hline 1 & 2.463 & 1.321 & 0.993 & 1.269 \\
\hline 2 & 2.494 & 0.956 & 0.979 & 1.382 \\
\hline 3 & 2.439 & 1.581 & 1.211 & 1.097 \\
\hline
\end{tabular}

Table -7: Comparison of Water absorption results

\begin{tabular}{|l|l|l|l|l|}
\hline \multirow{3}{*}{ S.No } & \multicolumn{4}{|l|}{ Average Water Absorption in \% } \\
\cline { 2 - 5 } & $\begin{array}{l}\text { Conventional } \\
\text { concrete }\end{array}$ & \multicolumn{3}{|l|}{ Bacterial concrete } \\
\cline { 2 - 5 } & 2.465 & $\mathbf{2 0 \%}$ & $\mathbf{3 0 \%}$ & $\mathbf{4 0 \%}$ \\
\hline 1 & & 1.286 & 1.061 & 1.249 \\
\hline
\end{tabular}

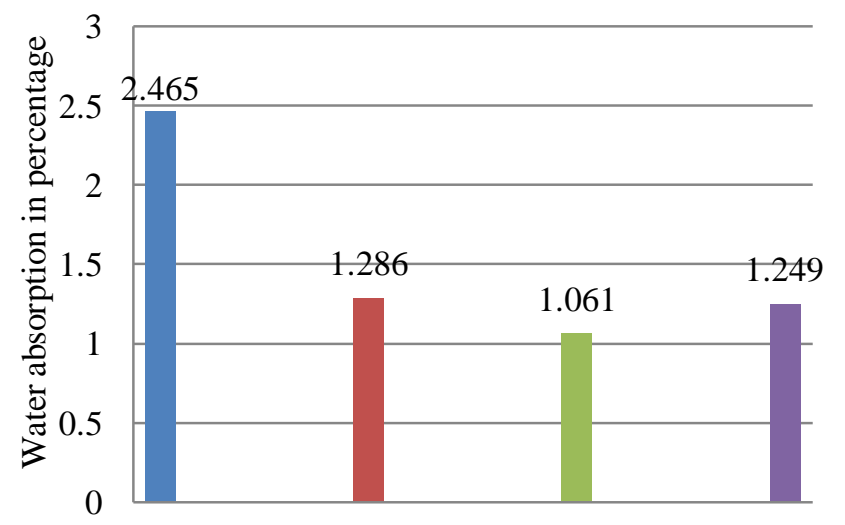

- Conventional Concrete $\quad 20 \%$ Bacterial Concrete $=30 \%$ Bacterial Concrete $\quad 40 \%$ Bacterial Concrete

Chart -6: Comparison of water absorption of concrete cubes in percentage

Based on the experimental result, the following were discussed.

$>$ Tests performed in this research suggest that the bacterial concrete is an interesting candidate for use in concretes for applications in the mixture.

$>$ The self healing nature was found in the concrete casted with bacterial solution. The cracks were found sealed with the calcium carbonate precipitate.

$>$ There is no change in the load carrying capacity, the compressive strength of the bacterial concrete when compared with the conventional concrete.

$>$ It is found that the compressive strength in case of concrete cubes casted with the bacteria is same when compared with the conventional concrete.

$>$ As expected relatively minor cracks in the concrete were sealed and henceforth the path to reinforcement is blocked.

$>$ From the obtained water absorption results, it is found that the bacterial concrete has lesser water absorption 
when compared to the conventional concrete and the water absorption and durability are inversely proportional to each other.

$>$ Concrete prepared by using bacteria gives aesthetically pleasant appearance.

$>$ The reinforcement corrosion that is caused due to the ingress of liquids and other ions can be stopped and thus the permeability can be reduced and hence the durability aspect of structures is enhanced.

$>$ Furthermore this method bacterial concrete will be very effective incase of underground structures and water retaining structures where repair is difficult or even impossible.

$>$ In order to overcome some of the durability problems, this method of using bacterial cell has become viable and it is even eco-friendly type of remediation.

$>$ The maximum amount of calcite precipitation occurred in the area close to the surface of the cracks in concrete cubes i.e., in the upper layer, middle layer and the lower layer. This is due to the fact that the bacterial cell grows at a higher rate in the presence of oxygen and induces precipitation of $\mathrm{CaCO}_{3}$ around the surface area of the cube.

\section{CONCLUSION}

From the discussion it is concluded that, the use of bacteria Sporosarcina Pasteurii in concrete can serve as the best option in Microbially Induced Calcite Precipitation due to its various special features. The method of self healing by the incorporation of bacteria into the concrete has greater advantage that it will save manual inspection, repair, time, money and moreover increase structure durability. The minor cracks in the structures can be remediated and the compressive strength of the concrete was found to be same as the conventional concrete. Since there is a lesser water absorption in the bacterial concrete, greater will be the durability of the concrete. Further study has to be carried out inorder to determine the limitation of percentage replacement of bacterial solution as only $20 \%, 30 \%$ and $40 \%$ of bacterial solutions were used in this study. The study exhibited that there are both advantage and even limitations about different healing agent and thus more research have to work as a further study.

\section{REFERENCES}

[1]. Al-Ghousian, I. \& Terro, M.(2002), "Use of Treated Wastewater for Concrete Mixing in Kuwait, Kuwait Journal of Science and Engineering, Vol.30, Issue 1:213-28.

[2]. Annie Peter .J, Lakshmanan.N, Devadas Manoharan.P, Rajamane.N.P\& Gopalakrishnan.S - "Flexural Behaviour of RC Beams Using Self Compacting Concrete", published in The Indian Concrete Journal, June 2004.

[3]. B. G. Jagadeesha Kumar, R Prabhakara, H. Pushpa, (March 2013), "Bio-Mineralization of Calcium Carbonate by Different Bacterial Strains and Their Application in Concrete Crack Remediation"
International Journal of Advances in Engineering \& Technology (IJAET), ISSN: 2231-19, Vol. 6, Issue 1.

[4]. C. C. Gavimath, B. M. Mali1,V. R. Hooli, J. D. Mallpur, A. B. Patil, D. P. Gaddi, C.R.Ternikar and B.E.Ravishankera. "Potential application of bacteria to improve the strength of cement concrete" published by International Journal of Advanced Biotechnology and Research ISSN 0976- 2612, Vol 3, Issue 1, 2012, pp 541-544.

[5]. Erik Schlangen,Senot Sangadji "Addressing Infrastructure Durability and Sustainability by Self Healing Mechanisms" - Recent Advances in Self Healing Concrete and Asphalt Published by Elsevier Ltd. Vol. 54 in 2013.

[6]. Hammes, N. Boon, J. De Villiers, W. Verstraete, S. D. Siciliano, and J. De Villiers, "Strain-Specific Ureolytic Microbial Calcium Carbonate Precipitation," published in Applied and Environmental Microbiology, vol.69, no.8, 2003, pp. 4901-4909.

[7]. J.Y. Wang, K. Van Tittelboom, N. De Belie1 and W. Verstraete. "Potential of Applying Bacteria to Heal Cracks in Concrete" published in conference on substantial construction materials and technologies in June2010.

[8]. Mayur Shantilal Vekariya, Prof. Jayeshkumar Pitroda "Addressing Infrastructure Durability and Sustainability by Self Healing Mechanisms" - Recent Advances in Self Healing Concrete and Asphalt Published by Elsevier Ltd. Vol. 54 in 2013.

[9]. Muhammad Isha, Afifudin. $\mathrm{H}$ and Mohd Saman H. "Bacillus Subtilis - And Thermus Thermophilis Derived Bioconcrete in enhancing concrete compressive strength", International sustainability and civil engineering journal, Vol. 1, No.1 (July 2012).

[10].M.V. Seshagiri Rao, V. Srinivasa Reddy, M. Hafsa, P. Veena and P. Anusha, June (2013), "Bioengineered Concrete - A Sustainable Self-Healing Construction Material" International science association congress, Research Journal of Engineering Sciences- ISSN 2278 - 9472, Vol. 2(6), 45-51.

[11].P. Tiano, L. Biagiotti, G. Mastromei, "Bacterial biomediated calcite precipitation for monumental stones conservation: methods of evaluation", published by Journal of Microbiological Methods, Vol.36, Issues 1-2, 1999.

[12].Rajesh K. Verma, Leena Chaurasia, Vishakha Bisht, Manisha Thakur (2015) "Bio-Mineralization and Bacterial Carbonate Precipitation in Mortar and Concrete", American Institute of Science (AIS) and Bioscience and Bioengineering, Vol. 1.

[13].S. Soundharya, Dr. K. Nirmalkumar, (July 2014), "Study on the Effect of Calcite-Precipitating Bacteria on Self-Healing Mechanism of Concrete", International Journal of Engineering Research \& Management Technology (IJERM), ISSN: 2348-4039, Volume 1, Issue-4.

[14].S. Silvia Hanah, N. Sakthieswaran (May 2015), "Mechanical Properties of Bio Mineralized Concrete", International Journal of Research in Engineering and 
Technology (IJRET), eISSN: 2319-1163 | pISSN: 2321 -7308, Volume: 04 Issue: 05.

[15].Srinivasa Reddy V, Sreenivasa Rao D, Seshagiri Rao M V, Sasikala Ch. "Permeation Properties of Bacterial Concrete" published in IOSR Journal of Mechanical and Civil Engineering (IOSR-JMCE) e-ISSN: 2278 -1684 Volume 5, Issue 6 (Mar. - Apr. 2013), PP 08-12.

[16].S. Sunil Pratap Reddy, M.V. Seshagiri Raob, P. Aparnac and Ch. Sasikalac. "Performance of standard grade bacterial (bacillus subtilis) concrete" published in asian journal of civil ngineering (building and housing) vol. 11, no. 1 (2010).

[17]. Srinivasa Reddy V, Achyutha Satya K, Seshagiri Rao M V, Azmatunnisa. "Biological approach to enhance strength and durability in concrete structures" published by International Journal of Advances in Engineering \& Technology, Sept 2012 Vol. 4, Issue 2, pp. 392-399.

[18].S.A. Abo-El-Enein , A.H. Ali , Fatma N. Talkhan , H.A. Abdel-Gawwad "Application of microbial bio-cementation to improve the physic-mechanical properties of cement mortar" published in HBRC Journal (2013).

[19].Vijeth N Kashyap, Radhakrishna, (Nov-2013), "A Study on Effect of Bacteria on Cement Composites" International Journal of Research in Engineering and Technology (IJRET), eISSN: 2319-1163 | pISSN: 2321 -7308, IC-RICE Conference Issue.

[20].Varenyam Achal; Abhijit Mukherjee; and M. Sudhakara Reddy. "Microbial Concrete: Way to Enhance the Durability of Building Structures "This paper is part of the Journal of Materials in Civil Engineering, Vol. 23, No. 6, June 1, page 730-734, 2011.

[21].V. Ramakrishnan, Ramesh K. Panchalan \& Sookie S. Bang, "Improvement of concrete durability by bacterial mineral precipitation", published by Elsevier. 